\title{
Countermeasures for the Development of Small- scale Border Trade of Yunnan Province
}

\author{
Zhiwei Tong \\ International Business School \\ Yunnan University of Finance and Economics \\ Kunming, China \\ 1031635541@qq.com
}

\author{
Ning Yan* \\ International Business School \\ Yunnan University of Finance and Economics \\ Kunming, China \\ ningyan68@126.com
}

\begin{abstract}
Small-scale border trade is a form of trade at the border areas. It is not only an important part of the import and export trade, but also the main way to develop an export-oriented economy at the border areas. Yunnan province is located in the southwestern border of China where plays an important role in bridging the foreign trade and economic, cultural exchanges between China and countries in Southeast Asia, South Asian. Since implementation of "the Reform and Opening-up Policy", China has made lots of strategic decisions such as "Western Development", "the Bridgehead Strategy in Yunnan" and "the Belt and Road Initiative", which provide stable environment and cooperation opportunities for the development of small-scale border trade of Yunnan province. It can be said that the smallscale border trade has become a featured card of Yunnan and plays an vital role in boosting economic development, improving employment opportunities, and promoting social stability of Yunnan province.
\end{abstract}

Small-scale border trade, takes into account that China is in the transition period of reform and development. Moreover, the current situation of small-scale border trade in Yunnan has been constantly changing, and actually many new problems have emerged. Based on these issues, the author put forward some opinions and suggestions in order to promote the healthy and sustainable development of small-scale border trade of Yunnan province.

Keywords-small-scale border trade of Yunnan province; current situation and problems; development strategy

\section{INTRODUCTION}

The small-scale border trade is the main form of Yunnan's border trade, accounting for a relatively large proportion of border trade in Yunnan province. At present, China is undergoing a period of reform and development, because of its unique geographical location, Yunnan has always played an irreplaceable role in Chinese external strategy, in spite of its role in the "western development strategy" or "one belt and one road strategy". Through the review of related articles, the author found that there has been few researches on small-scale border trade, especially in frontier provinces such as Yunnan. Nowadays, international trade is ever-changing, small-scale border trade is also no exception. As it continues to develop, there will also be faced with many new problems. However, most of the studies are based on a static point of view to provide advice on the development of small-scale border trade.

Based on a large number of related literature studies, this article specifically combines the current situation of small-scale border trade in Yunnan province, then from a dynamic perspective, focusing on the angle of the transformation and upgrading of industrial structure, and exploring the existing deficiencies and opportunities during the process of development of small-scale border trade in Yunnan province. Finally, to better promote the healthy and sustainable development of small-scale border trade of Yunnan province, the author proposes some corresponding countermeasures.

\section{LITERATURE REVIEW}

Small-scale border trade refers to enterprises in a country that have been approved to open to the outside world along the land border line, or in the border-city jurisdictions that have been approved to have small-frontier trade management rights trade with other companies or other trading organizations at border areas of neighboring countries through the statedesignated land ports. These include various trade forms such as barter trade and cash trade.

Small-scale border trade is not only an important part of the import and export trade, but also the main way to develop an export-oriented economy at the border areas. Our country has a land border line that is 18,000 kilometers longer than the coastline. Small-scale border trade plays an important role in boosting economic development, increasing employment opportunities, and promoting social stability in Yunnan. Now scholars, especially those who are at the border areas, are very interested in the topic of small-scale border trade and have conducted a lot of relevant researches.

With regard to the research on the factors that affect border trade, Kenneth Ronicki [1] focused on the study of the border and border effects between the two countries. He noted that differences in culture, systems, and regions determine the diversity of the borders, and these differences are also the main causes of the different border effects. Reed, Michael [2] conducted a study of the US-Mexico border trade. They claimed that the border effect factors constitute a higher level of regional trade, which has an critical impact on promoting cross-border trade. Donna Roberts [3] emphasized the difficulty of maintaining long-term cooperation between

*Corresponding author 
organizations and further pointed out two ways of cooperation: weak cooperation and mature cooperation. Keesing used U.S. census data in 1960 s to classify U.S. corporate workers into skilled and unskilled labor forces.

Relatively, domestic scholars have more research on smallscale border trade of Yunnan province, especially the question "how to change the status of small-scale border trade and determine the developmental direction of small-scale border trade of Yunnan province. For example, according to the statistical data from 1985 to 2014, Zhang [4] concluded that small-scale border trade of Yunnan province has a significantly positive correlation with local economic development and plays a catalytic role in it. Zhang [5] pointed out that there is a long-term co-integration relationship between Yunnan's Honghe Prefecture's economic growth and Vietnam's border trade. Peng [6] noted in the "Study on the Development of Yunnan-Vietnam Trade" that importation and exportation of products between Yunnan and Vietnam are single and low level. Du and Liang [7] pointed out that foreign trade in Yunnan, especially "the small-scale border trade", has developed rapidly in their analysis of the performance of Yunnan's foreign trade since China's accession to the WTO. Dai [8] stated in the "Analysis of the Problems and Countermeasures of Border Trade of Yunnan Province" that Yunnan Province should strengthen infrastructure construction; Optimizing trade structure and upgrading product levels; Speeding up the cultivation of talents and increasing investment in science and technology. Cao [9] emphasized that the status of China's small-scale border trade in the import and export structure is very weak and the macro conditions of small-scale border trade needs further improvement in the "China's Developmental Opportunities and Countermeasures of 'Small-scale Border Trade"".

In the above study on "The Small-scale Border Trade", most foreign scholars focused on the factors that affect the border trade, and they emphasized the theoretical level. There are less researches on the development of China's specific small-scale border trade. While domestic scholars have studied more on "Small-scale Border Trade", however, most scholars analyzed it from a fixed perspective. Moreover, the small-scale border trade of Yunnan province has also continued to evolve over time, therefore many new situations and problems will arise. But in this paper, the author adopt the latest data on the development of small-scale border trade of Yunnan province recent years, as well as combining the changes in the international and domestic macro-environment, then digging out the difficulties faced by the small-scale border trade in Yunnan province now, finally proposes some countermeasures and suggestions.

\section{CUREENT SituAtion OF YunNAN's SMALL-SCALE BORDER TRADE}

\section{A. Current Situation of the Small-scale Border Trade of Yunnan Province}

With 4061 kilometers of borders and nearly 200 ports at all levels, Yunnan Province is undoubtedly highly competitive in the development of the small-scale border trade under this geographical advantages. The following is divided into two sides: The first is to analyze the development status of the small-scale border trade of Yunnan province from the angle of small-scale border trade itself; The second part is to discuss the trade deficits about small-scale border trade between Yunnan province and other neighboring countries, that is to say, analyse the development of small-scale border trade of Yunnan province from an external perspective.

1) Trade volume of small-scale border trade of Yunnan province and its proportion in Yunnan's foreign trade

In 2015 and 2016, due to the unstable foundation of the global economic recovery, the existence of challenge factors such as trade frictions and the transformation of Yunnan's industries, the development of foreign trade in Yunnan became stagnated or even declined. (Figure 1) It shows that the total import and export volume of Yunnan Province in 2016 was $\$ 199.99$ billion, a decrease of $18.4 \%$ over the previous year. In which, the total export value was 11.582 billion U.S. dollars, drop by $30.3 \%$; the total import volume was 8.417 billion U.S. dollars, up $6.7 \%$.The annual import and export related to the EU market reached 1.003 billion U.S. dollars, a decrease of $33.1 \%$; the import and export in the ASEAN market was 11.833 billion U.S. dollars, down $10.2 \%$; the import and export about South Asia was 573 million U.S. dollars, drop by $48.1 \%$.Looking at the overall situation in 2017, affected by factors such as the continuous recovery of the global economy, the recovery of external demand, and the rebound in commodity prices, Yunnan province's foreign trade of importation and exportation showed a trend of recovery.

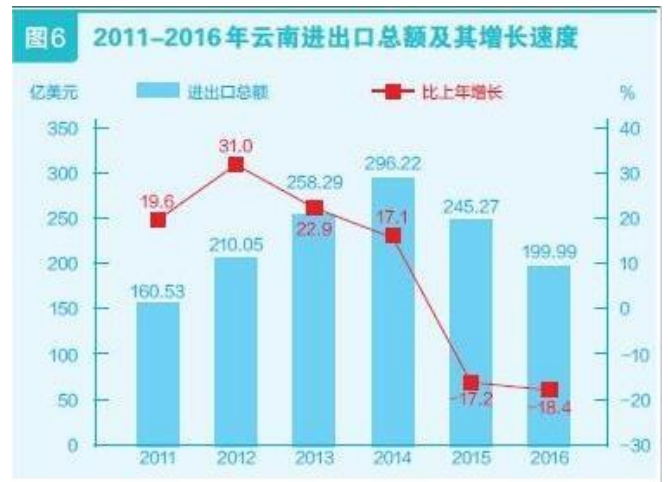

Data Source: Ministry of Commerce, Yunnan Province

Fig. 1. Total Imports and Exports of Yunnan, and Its Growth Rate in 20112016

According to statistics from Kunming Customs, in the first half of 2017, Yunnan's foreign trade that includes importation and exportation accounted for 63.13 billion yuan, an increase of $10.4 \%$ over the same period of the previous year. Especially in the month of June, Yunnan province's import and export volume was 12.27 billion yuan, which was the highest point in the first half of the year, and it's a 34\% growth. Moreover, among them, exports were 31.5 billion yuan, an increase of $1.3 \%$, imports were 31.63 billion yuan, an increase of $20.7 \%$, and the trade deficit was 130 million yuan. From January to June 2017, Yunnan province's general trade that includes importation and exportation amounted to 31.94 billion yuan, a decrease of $1 \%$, accounting for $50.6 \%$ of the total foreign trade volume of the province; And the province's small-scale border 
trade and frontier-to-city exchanges were 10.98 billion yuan and 10.68 billion yuan respectively, with an increase of $25.2 \%$ and $30.4 \%$ respectively. Besides, border trade accounted for $34.3 \%$ of the province's foreign trade, and processing trade that includes importation and exportation amounted to 6.4 billion, a decrease of $0.8 \%$.

In addition, according to the data analysis from 1985 to 2016, the small-scale border trade in Yunnan Province accounts for an average of about $20 \%$ of its foreign trade, which is enough to indicate that Yunnan's small-scale border trade plays an important role in Yunnan's foreign trade. Therefore, It is vital to attach sufficient importance to the development of small-scale border trade of Yunnan province, and allow it to play its due role then promotes regional economic development. (Yunnan Daily, Ministry of Commerce, Yunnan Province)

\section{2) Commodity structure of small-scale border trade in} Yunnan province

At present, Yunnan has formed six major backbone export product systems focusing on mechanical and electrical products, high-quality specialty agricultural products, phosphorus chemical products, textile and clothing, electric power and non-ferrous metal products. On the import side, because of the stable domestic economy and continued improvement in market demand, Yunnan province's imports have maintained a steady growth. The imported products are dominated by energy and raw materials, of which the increase in imports of agricultural products is particularly noticeable. Moreover, the rapid growth of product imports such as metal ore, coffee, soybeans has become the main driving force for the growth of Yunnan's foreign trade imports. In terms of exports, the main export categories are agricultural products, fertilizers and labor-intensive products. Since the beginning of this year, the export of agricultural products has continued to show a steady growth. This makes its top spot for export products has been secured. The province's export of agricultural products was 11.26 billion yuan, an increase of $11.8 \%$. From the perspective of the main trading entities, mainly focused on the state-owned enterprises and private enterprises, of which the development of private enterprises is the most prominent. Since 2010, private enterprises have become the main force for the recovery of Yunnan's import and export trade. The total value of foreign trade for imports and exports reached 7.324 billion U.S. dollars. Among them, exports were US\$5.179 billion and imports were US\$2.145 billion. More interesting was that the total value of foreign trade of private enterprises accounted for $54.8 \%$ of the total value of foreign trade in the province, an increase of $8.4 \%$ year-on-year.

\section{3) Small-scale border trade of Yunnan province is} transiting and optimizing

In recent years, Yunnan's foreign trade has been stabilizing in the challenge. The relevant departments are making efforts to create a "combination boxing" to help transform and upgrade the industrial structure of Yunnan enterprises and help them to go international.According to the statistics of the Yunnan Provincial Bureau of Statistics, the investment in fixed assets in Yunnan Province grew rapidly in 2017 and the investment structure continued to be optimized.Among them, investment in the three major industries has experienced a"two sectors increased and one decreased". From January to November, the province's primary industry completed an investment of 82.076 billion yuan, a year-on-year increase of 42.5\%; the secondary industry completed an investment of 2.540 trillion yuan, a decrease of $1.9 \%$, and investment in the tertiary industry. 13.34436 billion yuan, an increase of $21.8 \%$. It suggested that Yunnan Province is actively promoting the upgrading of its industrial structure, and the largest increase in investment in the tertiary industry is also the new high.

In summary, we can conclude that Yunnan Province is making great efforts to promote the transformation and upgrading of industrial structure.

4) Balance of small-scale border trade between Yunnan province and trading partners

ASEAN continues to maintain Yunnan's largest partner status. According to statistics from the Department of Commerce of Yunnan Province, from January to June 2017, imports and exports between Yunnan and ASEAN totaled 39.84 billion yuan, up $16.5 \%$, accounting for $63.1 \%$ of the province's total foreign trade volume. Among them, the top three trading countries are still Myanmar, Vietnam and Laos. The trade volume with Yunnan increased by $10.1 \%, 37.1 \%$ and $37.8 \%$ respectively; In the first half of 2017 , the total import and export volume of Yunnan and countries along the "One Belt and One Road" reached US\$6.23 billion, a year-on-year increase of $7.8 \%$.Among them, the import and export growth rates of countries along the UAE, Iran, the Philippines, Indonesia, etc., were rapid, with increases of $99.3 \%, 59.8 \%$, $41.7 \%$, and $45.8 \%$, respectively, this to a certain extent reflects the close cooperation between Yunnan and its neighboring countries, and shows that Yunnan has made great efforts to develop countries along "the One Belt and One Road".

In addition, although the deficit is continuously shrinking, the growth rate of small-scale border trade surplus of Yunnan province is still faster. As can be seen from Figure 1, the smallscale border trade of Yunnan province is almost always in a trade surplus position. On the whole, the balance of small-scale border trade a periodic fluctuation trend, which is clearly showing a three-phase fluctuation. The first phase is 1985-1996, the second phase is 1997-2008, and the third phase is 20092016.The third phase saw the largest increase. It was the period during which the balance of imports and exports of small-scale border trade of Yunnan province continued to expand. In 2015, it reached the peak of selected data. In summary, the changes in the balance of imports and exports of small-scale border trade of Yunnan province are closely related to the structure of Yunnan's export commodities. 


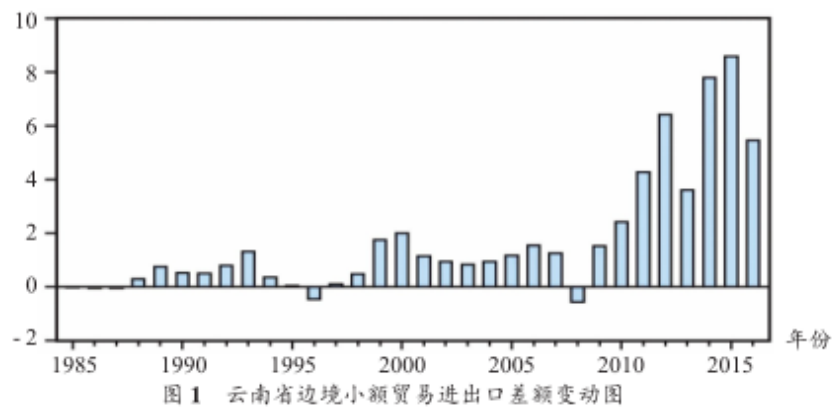

Data Source: Ministry of Commerce, Yunnan Province

Fig. 2. The import and export trade balance of small-scale border trade in Yunnan province

\section{INADEQUACIES OF SMALL-SCALE BORDER TRADE IN YUNNAN PROVINCE}

\section{A. Unreasonable Export Product Structure}

Yunnan Province has a limited variety of export products, and its product structure is relatively single. It mainly depends on traditional resource-intensive products, and the export volume of high-tech products is not large. At present, Yunnan mainly exports six key products including electromechanical products, agricultural products, phosphorus chemical products, textile and clothing, electric power and non-ferrous metal products. Among them, almost all of the four major products belong to primary manufacturing products, while agricultural products and mineral products have low technological content and low added value. The steady recovery of exports in the first half of 2017 was mainly driven by the increase in exports of agricultural products, fertilizers and some labor-intensive commodities. However, when we look at the data, we can see that the province's exports of major commodities, such as mechanical and electrical products, steel, and electricity, have declined, with declines of $3.2 \%, 27.7 \%$, and $2.3 \%$, respectively. This shows that the unfavorable situation such as the sluggish external demand, the singleness of its own commodity structure, and the lack of scale growth points has not been fundamentally changed. Yunnan's import and export commodities still are faced with problems of low product added value, low technological content, and high energy consumption.

\section{B. Excessive Concentration of Export Markets and Relatively Uniform Market Structure}

In recent years, the major export countries of Yunnan Province include Myanmar, Vietnam, India, Thailand, Malaysia, and Indonesia. Yunnan's export market is mainly concentrated in Asia, and it relies heavily on the ASEAN market. In 2017, the proportion of trade with Myanmar, Vietnam, and Laos increased from $49.9 \%$ in the same period of last year to $53.9 \%$, while the proportion of trade in developed markets such as the EU and the United States continued to shrink to 7.6\%.At the same time, the trade between Yunnan and Latin America 、South Asia and other emerging markets has problems such as low scale, single species, and significant fluctuations. In general, the structure of the border trade market in Yunnan province is not perfect, and it is too dependent on certain specific markets, which will lead to a decline of the ability to resist risks.

\section{High Transportation Costs}

Yunnan province, Burma, Laos, and Vietnam stand side by side and have no natural barriers on the border line of more than 4,000 kilometers. These natural geographical advantages provide Yunnan with strong conditions for carrying out smallscale border trade. However, Yunnan province has a high density of forests and the construction of transportation there is very difficult. The economy of Myanmar, Vietnam, and Laos is dominated by agriculture, so the industrial base is weak, and the overall national strength is weak. And the areas that are in contact with Yunnan are also poor and backward areas. This environment not only fails to meet the trade development of the three countries, but also deeply restricts the development of small-scale border trade in Yunnan province. Nowadays, although there are many roads and railways leading to Myanmar, Vietnam, and other countries, the traffic operation capacity is poor, and they were built in the last century. These roads are narrow, and there are many risks due to bending, and because of years of disrepair, they've already worn out.

\section{There is a Large Gap between Small-scale Border Trade of Yunnan Province and the Country, and the Small-scale Border Trade has a Low Trade Status}

According to statistics, in the first half of 2017, the national import and export volume was 13.1 trillion yuan, an increase of $19.6 \%$, of which exports were 7.2 trillion yuan, an increase of $15 \%$; imports were 5.9 trillion yuan, an increase of $25.7 \%$, and in spite of Yunnan was exporting at a rate of $1.3 \%$., or the overall increase of $10.4 \%$, there is still a big gap compared to the whole country. From the perspective of the proportion of small-scale border trade of Yunnan on foreign trade in Yunnan Province, the small-scale border trade of Yunnan Province is still relatively low compared with the national trade or other cities such as Heilongjiang and Guangxi provinces.

\section{COUNTERMEASURES TO PROMOTE DEVELOPMENT SMALL-SCALE BORDER TRADE IN YUNNAN PROVINCE}

- Providing opportunities for Yunnan's foreign trade and small-scale border trade transformation and upgrading through "cooperating and attracting giants". For one, the entry of large enterprises means the presence of capital and technology; For another, through participation in production and processing, Yunnan can participate in international division of labor and cooperation, integrate into the international industrial chain, and increase the influence in the international market, in addition, the high technology and high Value-added products can drive Yunnan's own industry transformation and upgrading.

- On the basis of consolidating traditional trading partners such as neighboring countries, Yunnan should actively target developed markets, especially the highly complementary markets like Hong Kong, Macao and Taiwan, Japan and South Korea, and use the "One Belt 
and One Road" opportunity to connect with markets in other regions.

- Relevant departments must make efforts to help Yunnan enterprises to go global, create a good social environment, and enhance the status of small-scale border trade of Yunnan province. Border trade must be developed and frontier people's income must be increased. First, we must vigorously develop the infrastructure construction in the border areas to provide a good internal and external environment for the border areas; Second, increasing the infrastructure construction in the border areas such as transportation, electricity, and improving the trading environment; Standardizing border trade port management, enhancing port capacity building to improve efficiency, improving border port work efficiency and service level, strengthening interdepartmental coordination, standardizing the bilateral market order in border trade, improving efficiency in handling affairs and customs clearance, and dare to innovate in patterns, to try.

- The commercial departments at all levels in Yunnan province should strengthen cooperation with customs, inspection and quarantine, taxation, banking, etc., performing their duties to ensure do a good job, and do not miss out. They also must optimize the business environment for foreign trade, improve the laws and regulations related to border trade, ensure that there are laws to follow, laws are obligatory, law enforcement is strict, and violations must be investigated.

- Enterprises that engage in border trade themselves must also bravely explore new roads. Enterprises can actively participate in key exhibitions, striving to be the leader in "going global", and vigorously expanding emerging markets such as the Middle East and Eastern Europe to increase their share of exports.

\section{CONCLUSION}

Through the review of literature related to the small-scale border trade of Yunnan province, and combining the author's own point of view, this article analyzes and explores the promotion of the development of small-scale border trade in Yunnan province.

Firstly, it analyzes the characteristics of small-scale border trade of Yunnan province the perspective of its own and externalities. Followed by the development of small-scale border trade of Yunnan province, including the advantages for developing small-scale border trade in Yunnan, its share in Yunnan's foreign trade, the commodity structure of small-scale border trade of Yunnan province, and the transformation and optimization of the industrial structure. Then pointed out the current deficiencies of small-scale border trade in Yunnan. One of the first concerns is the issue of industrial structure. This is also a problem that many scholars have not focused on. In this paper, it has become a key issue for small-scale border trade in Yunnan. The other deficiencies include the export market is too single, inadequate transport infrastructure, and financing issues for companies that engage in small-scale border trade in Yunnan. Finally, based on these issues, put forward the corresponding recommendations.

\section{REFERENCES}

[1] Kenneth Rolnicki, World Development Indicators, Washington:World Bank Publications, November 2011

[2] Reed,Michael, International Trade in Agriculture Products, NJ:Prentice Hall, 2010.

[3] Donna Roberts, Theory and Practice, London:Macmillan, 2010.

[4] Zhang Qun.Analysis of the correlation between small-scale trade in Yunnan and local economic development[J].Cooperative Economy and Technology, August 2017.

[5] Zhang Biqing.Empirical analysis of the border trade and economic growth between Fujian and Vietnam:Taking Honghe Prefecture of Yunnan as an example[J].Journal of Kunming University, December 2013.

[6] Peng Jian.Research on the development of Yunnan's trade with Vietnam[J].China Business, July 2013.

[7] Du Qiong, Liang Ping.Analysis of Yunnan Foreign Trade Performance since China's Entry into WTO[J].Exploration of Economic Issues, September 2012.

[8] Dian Yunzhen.On the problems and countermeasures of border trade in Yunnan province[J].Modern Shopping Mall, March 2012.

[9] Cao Kexue.Development opportunities and countermeasures for smallscale trade in China's border areas[J].June, 2012. 